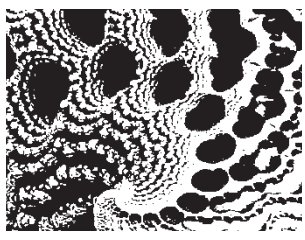

\title{
INNOVATION SYSTEMS IN CROATIAN REGIONS
}

Katarina BAČIĆ, Zoran ARALICA Institute of Economics, Zagreb

UDK: 001.895(497.5)

Izvorni znanstveni rad

Primlieno: 4. 2. 2015.

The goal of this paper was to research and apply the concept of Regional Innovation Systems (RIS) to Croatian regions and to identify particular strengths supporting innovation diffusion as a source of regional competitiveness. A system of indicators is envisaged, with the choice of RIS dimensions and indicators largely relying on Evangelista, lammarino, Mastrostefano, and Silvani (2001). In total, 32 relevant regional indicators are grouped into three dimensions - Knowledge creation and dissemination, Firm innovation activity and Systems' performance. Regional heterogeneity is noted with respect to innovation capacities in the 2006-2010 period: North-West Croatia is leading in the diffusion of innovation, with overall RIS configuration most conducive to innovation activity; Central and East Croatia (CEC) has a distinct value chain in agriculture and low-technology industries and industries' needs for technological upgrading are resolved through external R\&D (acquisition of licenses, patents and know-how), backed up by strong public financing; Adriatic Croatia is underperforming in innovation activity, given the advantages it has over CEC in important elements of systemic dimensions such as entrepreneurial and technological infrastructure and in scientific capacities. Policy implications are drawn from highlighted regional differences in innovation capacities and in sectoral structures.

Keywords: regional innovation system (RIS), Croatian regions, innovation activity, innovation diffusion

$\triangle$ Katarina Bačić, Institute of Economics, Trg J. F. Kennedyja 7, 10000 Zagreb, Croatia. E-mail: kbacic@eizg.hr

\section{INTRODUCTION}

In the last two decades there has been a growing research interest in regional innovation systems (RIS), a policy and research concept founded on the interaction between region- 
DRUŠ. ISTRAŽ. ZAGREB GOD. 25 (2016), BR. 2, STR. $157-178$

BAČIĆ, K., ARALICA, Z.: INNOVATION SYSTEMS... al institutions and organizations aiming for knowledge generation (invention) and knowledge diffusion (innovation) within the specific region (cf. Edquist, 2004). The purpose of RIS as a policy framework is to ensure the competitive advantage of regions by providing a supporting institutional and policy framework for turning local knowledge into innovation. Regional innovation policies have been on the European Union (EU) policy agenda since the mid-1990s, when focus shifted from underperforming national innovation systems (NIS) to encouraging innovation in less advanced regions, as a response to insufficiently competitive rates of innovation compared to those of the United States of America (Cooke \& Memedovic, 2003).

RIS as a research concept arises from systems of innovation literature and from regional research literature (Doloreux \& Parto, 2005). In the systems of innovation perspective, the innovation process emerges from interactions between agents operating in the system, where the innovation performance of the system largely depends on the quality of these interactions among agents - firms, universities and research centres (OECD, 2011). In regional research literature, innovation is a process attached to a spatial context, i.e. location, where the socio-institutional environment and economic structure traits are enabling the cooperation of firms and knowledge-creating and -diffusing institutions, such as universities and research institutes in innovation activities (Doloreux \& Parto, 2005). As a result of these broad theoretical foundations, there is no unified definition of RIS (EC, 2014), thus the concept remains open to different interpretations.

One interpretation of RIS is that it is a version of NIS restricted to regions. Following this view, methodologies for capturing innovative capacity on a national level were also applied to the regional level. These are mostly systems of indicators, representing different elements of an innovation system, across a few key dimensions. When these conceptual and statistical systems are consistently applied to countries or regions, composite indicators that enable benchmarking exercises and ranking can be constructed. This type of exercise is carried out by the European Commission for countries, in the Innovation Union Scoreboard (IUS) and for regions, in the Regional Innovation Scoreboard. Zabala-Iturriagagoitia, Jiménez-Sáez, Castro-Martinez, and Gutiérrez-Gracia (2007) reflect on this type of approach with criticism, seeing it biased due to the focus on high-technology sectors that is overshadowing the potential of other sectors and topics such as entrepreneurship, social and organisational innovation. Importantly, these authors also strongly advocate accounting for sociocul- 
DRUŠ. ISTRAŽ. ZAGREB GOD. 25 (2016), BR. 2 STR. $157-178$

BAČIĆ, K., ARALICA, Z.: INNOVATION SYSTEMS... tural and economic heterogeneity, in particular the heterogeneity of sectoral structures. Differences in industrial structures are also articulated by McCann and Ortega-Argilés (2013) as a source of regional diversity in providing different opportunities for innovation and entrepreneurship, along with the diversity of human capital structures, institutional set-up and quality of governance. Following this line of reasoning, regional differences can be turned into advantages and used as a starting point in deciding on regional growth and development models, rather than placing an imperative on European regions to follow the research and development and high-tech sector trajectory of the most progressive European regions (Hansen \& Winther, 2011).

Applying the RIS concept to Croatian regions is important for several reasons. Firstly, Croatia's innovative position relative to the other EU members has deteriorated post 2008, as reported in IUS 2015 (EC, 2015), an NIS-based report. An antecedent to the evolving of RIS in Croatia is the NIS concept applied to the Croatian context by Švarc $(2006 ; 2009)$, who has identified an obsolete science policy failing to capitalise on its science base as a major weakness. RISs may be considered as sub-sets or sub-systems of NIS, and further development of NIS clearly also depends on RIS's development. Secondly, studies that examine the economic performance of Croatian regions in terms of innovation capacities are rare. Thirdly, as to the issue of competitiveness of Croatian regions, in a very recent research, Đokić, Fröhlich, and Rašić Bakarić (2016) reported a widening of the productivity gap among Croatian regions in 2008-2012 and regional growth divergence. All of these factors point to a growing need for understanding the concept of RIS and placing it in the Croatian context of regional competitiveness.

Clearly, there is a gap in literature in researching and applying the RIS concept in the Croatian post-transition context. Thus, the goal of this paper is to research, conceptualise and apply a system of RIS indicators for Croatia. The main hypothesis of the paper is that by observing differences in the configuration of RISs across Croatia, particular strengths supporting sources of regional competitiveness can be identified. These strengths can be considered regional advantages, perceived through dimensions and elements of the RIS, while innovation diffusion can be observed as a source of regional competitiveness.

A system of indicators of regional innovation capacities is configured in this paper using descriptive statistics methods and in the elaboration of findings, relevant empirical litera- 
DRUŠ. ISTRAŽ. ZAGREB GOD. 25 (2016), BR. 2, STR. $157-178$

BAČIĆ, K., ARALICA, Z.: INNOVATION SYSTEMS.. ture is additionally referred to. The advantage of this approach is that it relies on the design of RIS founded on dimensions that each fall into spheres of influence of separate policies (SME-, innovation-, science and technology- and high-education policy), with the possibility of policy implications being drawn. The result of this research is that differences in innovation systems are noted across three regions: North-West Croatia is a forerunner in the diffusion of firm innovation, with overall RIS configuration most conducive to firm innovation activity; Central and East Croatia (CEC) is distinct with its value chain in agriculture and low-technology, with these industries' needs for technological upgrading being resolved through external R\&D (acquisition of licenses, patents and know-how) and largely backed up by public financing; Adriatic Croatia is underperforming in innovation activity, given the substantial advantages it has over CEC in a number of systemic dimensions (entrepreneurial \& technological infrastructure, scientific output).

The contribution of this paper is that it provides an overview of RISs in Croatia in the light of the competitiveness debate and highlights major differences in regional innovation capacities. Findings may also have implications for regional policies and may shed more light on the regional stance of various sectoral policies influencing innovation activity and competitiveness.

This paper consists of three major parts. The introduction is followed by a conceptual framework on RIS along with an overview of empirical findings from the relevant literature. In the second part, RIS is conceptualised and applied to Croatian data. In the third part, the differences in systems traits among three regions are analysed. The paper ends with a conclusion that contains policy recommendations.

\section{ANALYSIS OF REGIONAL INNOVATION SYSTEMS IN THE POST-TRANSITION CROATIAN CONTEXT}

\section{Overview of previous research}

There are a few reports tackling the issue of innovation systems and placing it in the context of competitiveness of Croatian regions. The report on the Regional Competitiveness Index of Croatia 2010 (NCC and UNDPCC 2011) is probably the most comprehensive in that it provides competitive profiles of Croatian regions, supplemented with a multitude of various economic, social and institutional indicators. Results have shown that the most developed regions were also the most competitive regions. Overall competiveness rankings 
DRUŠ. ISTRAŽ. ZAGREB GOD. 25 (2016), BR. 2 STR. 157-178

BAČIĆ, K., ARALICA, Z.: INNOVATION SYSTEMS... for 2007 and 2010 placed North-West Croatia (NWC) in a leading position, followed by Adriatic Croatia (AC) and Central and East Croatia (CEC). The importance of innovative capacity can be assessed using perception-based indicators of technology \& innovativeness and clusters. Counties where major urban centres are situated (Zagreb, Rijeka, Osijek, Zadar) are most favourably ranked, along with three more counties in NWC (County of Varaždin, County of Koprivnica-Križevci and County of Međimurje).

Important reports on regional innovation potential are EU's Regional Innovation Scoreboard 2014 (EU-RIS-14) (EC, 2014) and the EU Regional Competitiveness Index 2013 (EU-RCI-13) (JRC, 2013). EU-RIS-14 is a version of the Union Innovation Scoreboard extended to regions. EU-RIS-14 ranks regions into four regional innovation performance groups leaders, followers, moderate innovators and modest innovators, using 11 indicators grouped into three dimensions Enablers, Firm activities and Outputs. ${ }^{1}$ EU-RIS-14 ranks NWC as a moderate innovator and CEC and AC as modest innovators. CEC made progress in 2008, albeit temporary, when it was upgraded to a moderate innovator. Data availability for Croatian regions amounted to only $28.8 \%$, while the rest of the data were estimated. Another trait of EU-RIS-14 is a large focus on small and medium-sized firms due to statistical reasoning: the activity of larger enterprises that perhaps innovate outside the headquarter region is registered in the headquarter region, so including these firms would create a distorted image of spatial distribution of innovation activity. However, larger enterprises are the key carriers of innovation activity in Croatia (CBS, 2008j).

EU-RCI-13 is also a pan-European report that ranks regions based on scores across 11 pillars, one of them being the Innovation pillar with 12 indicators. According to the Innovation pillar score, Continental Croatia (including both NWC and CEC) was ranked 193 and Adriatic Croatia was ranked 219 out of 262 observed regions, while these regions' overall competitiveness ranking was more unfavourable, 213 and 225, consecutively. While EU-RIS-14 offers more indicators on firm-related investment, on entrepreneurship and on SME innovation output, EU-RCI-13 offers distinct indicators on patents in rising sectors such as ICT and biotechnology, as well as cluster indicators for high-tech clusters. However, the data for the latter indicator are again missing for Croatian regions.

The European reports dealing with regional innovation capacities and competitiveness are most useful in the sense that they position regions in the EU's economic space and 
DRUŠ. ISTRAŽ. ZAGREB GOD. 25 (2016), BR. 2, STR. $157-178$

BAČIĆ, K., ARALICA, Z.: INNOVATION SYSTEMS... that they are indicative of major advantages and problem-areas of innovation activity at regional level. Their obstacle for policy use is that important innovation-related dimensions such as regional human resources, education and research systems are poorly represented with indicators at this level of research. Moreover, data for Croatian regions are missing across a number of used indicators. The sectoral focus of these reports is mostly on high-tech and knowledge intensive sectors, making it possible to dismiss regional advantages related to technologically less complex economic sectors. Motivation for designing a more integral analytical framework stems from the outlined arguments and from a need to examine the usefulness of the RIS concept for policy purposes by including a higher number of relevant indicators across more dimensions, drawing on the Community innovation survey (CIS) for Croatia and on other relevant data sources.

\section{Designing an RIS as an analytical framework for Croatia}

The first methodological difficulty in RIS research is in defining what a region in Croatia is. The county administrative division is far too fragmented to be considered appropriate for studying RISs in Croatia. Therefore, the NUTS II level of aggregation (Eurostat, 2015) valid in the observed period is consorted to, and NWC, CEC and AC are considered appropriate statistical units. Nevertheless, the NUTS II level are not administrative units in Croatia and thus overarching "top-down" regional policies per se do not exist at this level. Given the fact that this is not a fully functional RIS, the potential of an innovation system within a given territory is actually examined.

RIS, consisting of 32 indicators across three dimensions that are in the spirit of the Triple Helix model of University, Industry and Government relations (Etzkowitz \& Leydesdorff, 1995) is conceptualised. The choice of indicators and dimensions rely largely on Evangelista, Iammarino, Mastrostefano, and Silvani (2001). Using descriptive statistics' methods, 28 indicators are constructed using Croatian CIS, a research on firms' innovation activity and other relevant data sources for the period 2006-2010, while four indicators are directly referred to NCC and UNDPPC (2011) as the original data source. The approach is presented in Table 1 . The role of universities and other research institutions in innovation systems is examined through the "Knowledge creation and dissemination" dimension. Firm innovation activity is analysed through 17 indicators based on CIS data. The "System's performance" di- 
(1) TABLE 1

Choice of RIS

indicators for Croatia

for 2006-08 and 2008-10 mension includes a number of indicators which indicate whether innovation systems are supportive in facilitating the diffusion of innovation.

\begin{tabular}{|c|c|c|c|}
\hline & Dimensions and elements & Description of the indicator & Source of data \\
\hline I & \multicolumn{3}{|l|}{ Knowledge creation and dissemination } \\
\hline 1.1. & \multicolumn{3}{|l|}{ Human resources development } \\
\hline & $\begin{array}{l}\text { Population of } 25-64 \text { years of age in } \\
\text { total population, in } \%\end{array}$ & In 2001 and 2011. & CBS (a), (b) \\
\hline & $\begin{array}{l}\text { Population with higher level education } \\
\text { (polytechnic schools) in population of } \\
24-65 \text { years of age, in } \%\end{array}$ & In 2011. & CBS (c), (b) \\
\hline & $\begin{array}{l}\text { Population with highest level education } \\
\text { (universities) in population of } 24-65 \text { years } \\
\text { of age, in } \%\end{array}$ & In 2011. & CBS (c), (b) \\
\hline & $\begin{array}{l}\text { Students enrolled in pop. of } 20-24 \\
\text { years of age in population of } 20-24 \\
\text { years of age, in } \%\end{array}$ & $\begin{array}{l}\text { Students enrolled in winter semester by their } \\
\text { residence in } 2007 \text { and } 2010 \text {, as \% in popu- } \\
\text { lation of } 20-24 \text { years of age ( } 2011 \text { Census). }\end{array}$ & CBS (d), (c) \\
\hline & $\begin{array}{l}\text { Students graduated in pop. of } 20-24 \\
\text { years of age, in } \%\end{array}$ & $\begin{array}{l}\text { Students by their residence, as \% in popu- } \\
\text { lation of } 20-24 \text { years of age ( } 2011 \text { Census), } \\
\text { in } 2007 \text { and in } 2010 .\end{array}$ & CBS (d), (c) \\
\hline & $\begin{array}{l}\text { Masters of Science, Masters and } \\
\text { University sity Specialists/Students } \\
\text { graduated, in \% }\end{array}$ & $\begin{array}{l}\text { Degrees/titles by University location for } \\
2007-08 \text { (annual average)/Students graduated } \\
\text { in 2007; Degrees/titles by University location } \\
\text { for 2009-10 (annual average)/Students } \\
\text { graduated in } 2010 .\end{array}$ & $\begin{array}{l}\text { CBS } \\
(\mathrm{e}),(\mathrm{f}),(\mathrm{d}),(\mathrm{c})\end{array}$ \\
\hline & $\begin{array}{l}\text { Doctors of Science/Students } \\
\text { graduated, in } \%\end{array}$ & $\begin{array}{l}\text { Doctors of science aggregated by University } \\
\text { location in } 2008 \text { and 2010/Students graduated } \\
\text { in } 2007 \text { and } 2010 .\end{array}$ & $\begin{array}{l}\text { CBS } \\
(\mathrm{e}),(\mathrm{f}),(\mathrm{d}),(\mathrm{c})\end{array}$ \\
\hline \multirow[t]{4}{*}{1.2.} & \multicolumn{3}{|l|}{ Scientific infrastructure } \\
\hline & $\begin{array}{l}\text { Number of scientific research } \\
\text { institutions }\end{array}$ & $\begin{array}{l}\text { Number of public and private scientific } \\
\text { research institutions. }\end{array}$ & MSES and BC \\
\hline & $\begin{array}{l}\text { Academic staff per institution of } \\
\text { higher education }\end{array}$ & $\begin{array}{l}\text { Academic staff in the academic year 2008/09 } \\
\text { and in 2010/11/No. of institutions of higher } \\
\text { education. }\end{array}$ & CBS (f), (e) \\
\hline & $\begin{array}{l}\text { Students enrolled per } \\
\text { academic staff member }\end{array}$ & $\begin{array}{l}\text { Students enrolled in 2007/Academic staff in } \\
\text { 2008/09; Students enrolled in 2010/Academic } \\
\text { staff in 2010/11. }\end{array}$ & $\begin{array}{l}\text { CBS } \\
(\mathrm{d}),(\mathrm{c}),(\mathrm{e}),(\mathrm{f})\end{array}$ \\
\hline \multirow[t]{2}{*}{1.3.} & \multicolumn{3}{|l|}{ Scientific output } \\
\hline & $\begin{array}{l}\text { Number of publications published in } \\
\text { scientific databases per scientific } \\
\text { institution }\end{array}$ & $\begin{array}{l}\text { Number of original scientific papers published } \\
\text { in Scopus and Web of Science databases in } \\
2007-08 \text { and 2009-2010/No. of scientific institutions. }\end{array}$ & CROSBI \\
\hline II & \multicolumn{3}{|l|}{ Firm innovation activity } \\
\hline 2.1. & \multicolumn{3}{|l|}{ Industrial structure, $\%$ of firms in: } \\
\hline & Low-technology intensive industry & - & CBS-CIS \\
\hline & Medium-low technology intensive industry & - & CBS-CIS \\
\hline & Medium-high technology intensive industry & $y-$ & CBS-CIS \\
\hline & High-technology intensive industry & - & CBS-CIS \\
\hline & Low-knowledge intensive service industry & - & CBS-CIS \\
\hline & Knowledge-intensive service industry & - & CBS-CIS \\
\hline
\end{tabular}

(continued) 
(1) TABLE 1 (continued)

\begin{tabular}{|c|c|c|c|}
\hline & Dimensions and elements & Description of the indicator & Source of data \\
\hline \multirow[t]{3}{*}{2.2 . } & Firms' characteristics & & CBS-CIS \\
\hline & Firm size & Number of employees. & CBS-CIS \\
\hline & Employees with university degree & $\begin{array}{l}\text { Classes with respect to } \% \text { of employees } \\
\text { with a university degree in firms in } 2010 \text { : } \\
0 \text { for } 0 \%, 1 \text { for } 1 \% \text { to } 4 \%, 2 \text { for } 5 \% \text { to } 9 \% \text {, } \\
3 \text { for } 10 \% \text { to } 24 \%, 4 \text { for } 25 \% \text { to } 49 \%, 5 \text { for } 50 \% \\
\text { to } 74 \%, 6 \text { for } 75 \% \text { to } 100 \% \text {. }\end{array}$ & CBS-CIS \\
\hline \multirow[t]{6}{*}{2.3 . } & Firms performance & & \\
\hline & 2.3.1. Innovation input & & \\
\hline & $\begin{array}{l}\text { In-house R\&D: Acquisition of } \\
\text { machinery, equipment, and software, } \\
\text { in } 000 \text { kuna }\end{array}$ & $\begin{array}{l}\text { Amount of expenditure divided } \\
\text { by the number of employees. }\end{array}$ & CBS-CIS \\
\hline & $\begin{array}{l}\text { External R\&D: Acquisition of external } \\
\text { knowledge (licences, patents, } \\
\text { know-how), in } 000 \text { kuna }\end{array}$ & $\begin{array}{l}\text { Amount of expenditure divided by the } \\
\text { number of employees. }\end{array}$ & CBS-CIS \\
\hline & 2.3.2. Innovation output & & \\
\hline & $\begin{array}{l}\text { Turnover from significantly improved } \\
\text { products introduced new to market/new } \\
\text { to firm in total turnover }\end{array}$ & - & CBS-CIS \\
\hline III & System's performance & & \\
\hline \multirow[t]{2}{*}{3.1.} & Diffusion of innovation & & \\
\hline & $\%$ of innovative firms & - & CBS-CIS \\
\hline \multirow[t]{3}{*}{3.2 . } & $\begin{array}{l}\text { Public financial support, } \% \text { of firms that } \\
\text { received financing for innovation } \\
\text { activities from: }\end{array}$ & & \\
\hline & Local and regional authorities & - & CBS-CIS \\
\hline & National authorities & - & CBS-CIS \\
\hline \multirow[t]{4}{*}{ 3.3. } & $\begin{array}{l}\text { Innovation factors, } \% \text { of firms } \\
\text { that found important: }\end{array}$ & & \\
\hline & $\begin{array}{l}\text { Internal sources of information } \\
\text { about innovation }\end{array}$ & $\begin{array}{l}\text { Sources within the enterprise (group) } \\
\text { perceived as highly important. }\end{array}$ & CBS-CIS \\
\hline & $\begin{array}{l}\text { Market sources of information } \\
\text { about innovation }\end{array}$ & $\begin{array}{l}\text { Sources from suppliers of equipment, } \\
\text { materials, etc., from clients or customers, } \\
\text { from competitors and other enterprises } \\
\text { of same industry, from consultants, } \\
\text { commercial labs or private R\&D institutes } \\
\text { perceived as highly important and of } \\
\text { medium-high importance. }\end{array}$ & CBS-CIS \\
\hline & $\begin{array}{l}\text { Institutional sources of information } \\
\text { about innovation }\end{array}$ & $\begin{array}{l}\text { Sources from Universities or other higher } \\
\text { education institutes, Government or public } \\
\text { research institutes, perceived as highly } \\
\text { important and of medium-high importance. }\end{array}$ & CBS-CIS \\
\hline \multirow[t]{5}{*}{3.4 . } & Infrastructure and competitiveness & & \\
\hline & $\begin{array}{l}\text { Business zones surface } \\
\left(\mathrm{m}^{2} \text { per capita }\right)\end{array}$ & In 2006 and 2007. & $\begin{array}{l}\text { NCC and } \\
\text { UNDPPC, } 2011\end{array}$ \\
\hline & $\begin{array}{l}\text { Number of employed in SMEs } \\
\text { per capita }\end{array}$ & In 2006 and in 2009. & $\begin{array}{l}\text { NCC and } \\
\text { UNDPPC, } 2011\end{array}$ \\
\hline & $\begin{array}{l}\text { SMEs' investment into new long-term } \\
\text { assets/total revenues }\end{array}$ & In 2006 and in 2009. & $\begin{array}{l}\text { NCC and } \\
\text { UNDPPC, } 2011\end{array}$ \\
\hline & $\begin{array}{l}\text { Gross value added (GVA) per employee } \\
\text { in industry, in } 000 \text { kuna }\end{array}$ & In 2004 and in 2008. & $\begin{array}{l}\text { NCC and } \\
\text { UNDPPC, } 2011\end{array}$ \\
\hline
\end{tabular}




\section{REGIONAL INNOVATION SYSTEM PERFORMANCE}

The Croatian regions' economic position is presented using data in Table 2. NWC's position is unrivalled. This region's environment for innovation activity is most advantageous, as seen in its central position, presence of the capital-city and superior economic results: with a $38 \%$ share of Croatian population, NWC produced roughly $48 \%$ of the Croatian GDP in

(1) TABLE 2

Basic territorial, demographic, economic and development indicators of Croatian regions
2010. Furthermore, the capital-city Zagreb also hosts the highest number of entrepreneurs. ${ }^{2}$ FDI and international trade, both important sources of innovation that enable knowledge spillovers (Hashi \& Stojčić, 2013) are drawn to NWC.

\begin{tabular}{lrrr}
\hline & $\begin{array}{r}\text { North-West } \\
\text { Croatia }\end{array}$ & $\begin{array}{r}\text { Central and East } \\
\text { Croatia }\end{array}$ & $\begin{array}{r}\text { Adriatic } \\
\text { Croatia }\end{array}$ \\
\hline Surface $\left(\mathrm{km}^{2}\right)$ & 8.669 & 23.220 & 24.705 \\
$\quad$ share in total, $\%$ & $15 \%$ & $41 \%$ & $44 \%$ \\
Number of inhabitants (2009) & 1.672 .507 & 1.287 .650 & 1.468 .921 \\
$\quad$ share in total, \% & $38 \%$ & $29 \%$ & $33 \%$ \\
GDP, in mil. EUR (2010) & 21.336 & 8.608 & 14.497 \\
$\quad$ share in total & $48 \%$ & $19 \%$ & $32 \%$ \\
Agriculture* (2010) & $0.8 \%$ & $5.7 \%$ & $1.6 \%$ \\
Industry* (2010) & $30.3 \%$ & $36.1 \%$ & $28.2 \%$ \\
Market services* (2010) & $68.9 \%$ & $58.2 \%$ & $70.2 \%$ \\
GDP per capita, in EUR (2010) & 12.278 & 6.745 & 9.876 \\
Export per capita, in EUR & 2.878 & 1.250 & 1.638 \\
FDI per capita, in EUR (2005-09) & 6.814 & -52.0 & 1.955 \\
\hline
\end{tabular}

Source

NCC and UNDP (2011) for surface, number of inhabitants' and FDI data; Authors' calculations of GDP based on CBS (g), and of export per capita based on CBS (h).

Remarks

*Aggregated to regional level using county shares in regional employment (in legal person) as weights, based on CBS (i) data.

While AC's share in population and in GDP is approximately matching, CEC's position is "peripheral": $29 \%$ share in population and only 19\% share in national GDP, a relation that points to lower-value added activities compared to the other two regions. There is sectoral similarity between NWC and $\mathrm{AC}$ in the high shares of services sector represented in employment structures, $68.9 \%$ and $70.2 \%$ respectively, while CEC has a more pronounced orientation to agriculture and a lower share of market services.

In the next sections the RIS concept is applied to Croatian data (Table 3) and the results are analysed. 
(1) TABLE 3

RIS concept applied

to Croatian data

\begin{tabular}{|c|c|c|c|c|c|c|c|}
\hline & \multirow[b]{2}{*}{ Dimension and its variables } & \multicolumn{3}{|c|}{$\begin{array}{r}2006-2008 \\
\text { Regions }\end{array}$} & \multicolumn{3}{|c|}{$\begin{array}{r}\text { 2008-2010 } \\
\text { Region }\end{array}$} \\
\hline & & $\begin{array}{l}\text { North- } \\
\text {-West } \\
\text { Croatia }\end{array}$ & $\begin{array}{r}\text { Central } \\
\text { and East } \\
\text { Croatia }\end{array}$ & $\begin{array}{r}\text { Adriatic } \\
\text { Croatia }\end{array}$ & $\begin{array}{l}\text { North- } \\
\text {-West } \\
\text { Croatia }\end{array}$ & $\begin{array}{r}\text { Central } \\
\text { and East } \\
\text { Croatia }\end{array}$ & $\begin{array}{l}\text { Adriatic } \\
\text { Croatia }\end{array}$ \\
\hline I & Knowledge creation and dissemination & & & & & & \\
\hline \multirow[t]{8}{*}{ 1.1. } & Human resources development & & & & & & \\
\hline & $\begin{array}{l}\text { Population of } 25-64 \text { years of age in } \\
\text { total population, in } \%\end{array}$ & 54.4 & 52.1 & 53.2 & 56.2 & 53.9 & 55.4 \\
\hline & $\begin{array}{l}\text { Population with higher level education } \\
\text { in population of } 24-65 \text { years of age, in } \%\end{array}$ & - & - & - & 8.9 & 7.0 & 10.6 \\
\hline & $\begin{array}{l}\text { Population with highest level education in } \\
\text { population of } 24-65 \text { years of age, in } \%\end{array}$ & - & - & - & 20.9 & 9.8 & 15.9 \\
\hline & $\begin{array}{l}\text { Students enrolled in pop. of } 20-24 \text { years of } \\
\text { age in population of } 20-24 \text { years of age, in } \%\end{array}$ & 51.3 & 42.3 & 53.8 & 58.3 & 46.4 & 59.7 \\
\hline & $\begin{array}{l}\text { Students graduated in pop. of } 20-24 \\
\text { years of age, in \% }\end{array}$ & 8.6 & 5.9 & 8.6 & 11.9 & 10.1 & 13.9 \\
\hline & $\begin{array}{l}\text { Masters of Science, Masters and University } \\
\text { Specialists/Students graduated, in } \%\end{array}$ & 7.1 & 1.9 & 2.0 & 5.0 & 2.2 & 1.3 \\
\hline & Doctors of Science/Students graduated, in \% & 4.7 & 0.7 & 0.8 & 5.5 & 0.7 & 1.1 \\
\hline \multirow[t]{4}{*}{1.2 . } & Scientific infrastructure & & & & & & \\
\hline & Number of scientific research institutions & 112 & 23 & 43 & 114 & 24 & 45 \\
\hline & Academic staff per institution of higher education & 119.7 & 83.5 & 119.1 & 125.6 & 88.8 & 125.5 \\
\hline & Students enrolled/Academic staff & 6.5 & 15.7 & 9.1 & 6.7 & 16.8 & 9.2 \\
\hline \multirow[t]{2}{*}{1.3 . } & Scientific output & & & & & & \\
\hline & $\begin{array}{l}\text { Number of publications published } \\
\text { in scientific databases per institution }\end{array}$ & 72 & 24 & 54 & 81 & 26 & 66 \\
\hline II & Firm innovation activity & & & & & & \\
\hline \multirow[t]{7}{*}{2.1.} & Industrial structure, $\%$ of firms in: & & & & & & \\
\hline & Low-technology intensive industry & 19.3 & 26.1 & 13.9 & 18.4 & 27.1 & 14.5 \\
\hline & Medium-low technology intensive industry & 12.7 & 13.9 & 14 & 12.2 & 13.5 & 15.1 \\
\hline & Medium-high technology intensive industry & 7.4 & 5.7 & 7.8 & 7.0 & 5.0 & 4.1 \\
\hline & High-technology intensive industry & 2 & 0.7 & 1 & 2.0 & 0.9 & 0.6 \\
\hline & Low-knowledge intensive service industry & 23 & 19.1 & 29.8 & 23.3 & 18.1 & 29.4 \\
\hline & Knowledge-intensive service industry & 17.4 & 4.6 & 9.6 & 19.2 & 7.3 & 11.5 \\
\hline \multirow[t]{3}{*}{2.2 . } & Firms' characteristics & & & & & & \\
\hline & Firm size & 168.5 & 94.9 & 106.4 & 148.4 & 93.2 & 97.2 \\
\hline & Employees with university degree & - & - & - & 2.2 & 1.51 & 1.98 \\
\hline \multirow[t]{4}{*}{2.3 . } & Firms performance & & & & & & \\
\hline & 2.3.1. Innovation Input & & & & & & \\
\hline & $\begin{array}{l}\text { In-house R\&D: Acquisition of machinery, } \\
\text { equipment, and software, in kuna, in } 000\end{array}$ & $1.348,9$ & 166,8 & 278,4 & 734,7 & 33,1 & 45,0 \\
\hline & $\begin{array}{l}\text { External R\&D: Acquisition of external } \\
\text { knowledge (licences, patents, know-how), } \\
\text { in kuna, in } 000\end{array}$ & $3.452,8$ & $1.819,3$ & $1.315,7$ & 274,4 & 270,2 & 106,5 \\
\hline
\end{tabular}

(continued) 


\begin{tabular}{|c|c|c|c|c|c|c|c|}
\hline & \multirow[b]{2}{*}{ Dimension and its variables } & \multicolumn{3}{|c|}{$\begin{array}{r}2006-2008 \\
\text { Regions }\end{array}$} & \multicolumn{3}{|c|}{$\begin{array}{r}2008-2010 \\
\text { Regions }\end{array}$} \\
\hline & & $\begin{array}{r}\text { North- } \\
\text {-West } \\
\text { Croatia }\end{array}$ & $\begin{array}{r}\text { Central } \\
\text { and East } \\
\text { Croatia }\end{array}$ & $\begin{array}{l}\text { Adriatic } \\
\text { Croatia }\end{array}$ & $\begin{array}{r}\text { North- } \\
\text {-West } \\
\text { Croatia }\end{array}$ & $\begin{array}{r}\text { Central } \\
\text { and East } \\
\text { Croatia }\end{array}$ & $\begin{array}{r}\text { Adriatic } \\
\text { Croatia }\end{array}$ \\
\hline & \multicolumn{7}{|l|}{ 2.3.2. Innovation Output } \\
\hline & $\begin{array}{l}\text { Turnover from significantly improved } \\
\text { products introduced new to market/ } \\
\text { new to firm in total turnover }\end{array}$ & 32.1 & 35.5 & 35 & 28.8 & 31.8 & 33.4 \\
\hline \multirow{3}{*}{$\begin{array}{l}\text { III } \\
3.1 .\end{array}$} & System's performance & & & & & & \\
\hline & Diffusion of innovation & & & & & & \\
\hline & $\%$ of innovative firms & 51.6 & 43.2 & 44.7 & 50.2 & 40.4 & 40.2 \\
\hline \multirow[t]{3}{*}{3.2.} & $\begin{array}{l}\text { Public financial support, } \% \text { of firms which } \\
\text { receive financing for innovation activities from: }\end{array}$ & & & & & & \\
\hline & Local and regional authorities & 3.7 & 8.1 & 5.8 & 5.4 & 5.4 & 4.2 \\
\hline & National authorities & 22.2 & 29.6 & 21.2 & 24.6 & 30.4 & 17.6 \\
\hline \multirow[t]{4}{*}{ 3.3. } & Innovation factors, $\%$ of firms that found importa & ant: & & & & & \\
\hline & Internal sources of information about innovation & 32.0 & 25.8 & 25.3 & 31.1 & 23.6 & 19.7 \\
\hline & Market sources of information about innovation & 36.0 & 31.6 & 30.3 & 34.5 & 26.9 & 25.2 \\
\hline & $\begin{array}{l}\text { Institutional sources of information } \\
\text { about innovation }\end{array}$ & 13.5 & 12.6 & 8.8 & 7.8 & 5.2 & 4.2 \\
\hline \multirow[t]{5}{*}{3.4.} & Infrastructure and competitiveness & & & & & & \\
\hline & Business zones surface (m2 per capita) & 13.9 & 6.3 & 11.2 & 18.3 & 18.0 & 18.4 \\
\hline & Number of employed in SMEs per capita & 16.2 & 9.0 & 12.7 & 16.8 & 9.0 & 12.9 \\
\hline & $\begin{array}{l}\text { SMEs' investment into new long-term } \\
\text { assets/total revenues }\end{array}$ & 8.2 & 7.4 & 12.0 & 5.3 & 5.2 & 8.2 \\
\hline & GVA per employee in industry, in 000 kuna & 202.5 & 117.2 & 151.6 & 227.3 & 141.4 & 195.2 \\
\hline
\end{tabular}

\section{Knowledge creation and dissemination}

The importance of knowledge creation and dissemination for innovation activity in Croatian regions can be observed through the role of public Universities and research institutes that are subject to national scientific policy and financing. Transition from the traditional scientific policy focused dominantly on scientific research in the public research sector as a driver of innovation to modern innovation policy, which requires interaction between the science and industry spheres, has been slow and has caused considerable resistance within the scientific community itself (Švarc, 2009). Scientific policy is highly centralised and its main features in the 2006-2010 period are the tightening of the science and higher education budget, adjusting the standards of quality to the EU through the Bologna process and announcing rising standards for scientific output. In the context of the latter goal, cooperation between science and business is slowly becoming prioritised as a modus of financing scientific research projects. 
DRUŠ. ISTRAŽ. ZAGREB GOD. 25 (2016), BR. 2, STR. $157-178$

BAČIĆ, K., ARALICA, Z.: INNOVATION SYSTEMS...
While formally universities are both hubs of human resources development and undertake scientific research, a distinct traditional feature of the national scientific system is the reliance on research institutes in producing applied research (Švarc, 2006), representing potential to be transformed into innovation. The most potent private and public research institutions with considerable success in applied science are located mostly in NWC. University programmes in the capital city cover a broad spectrum of specialisations and degrees, serving both regional and national demand for tertiary education.

Simultaneously, an educational mismatch exists in the labour market that can partly be explained by Croatian universities' inertia towards the knowledge economy (Dabić \& Švarc, 2012). Skills and knowledge mismatch is another problematic trait pertaining to the labour market (EIZ, 2016) with possible negative effects on firms' innovation capacities. Božić and Botrić (2014) have found the presence of a highly-educated labour force to be an important factor for firm innovation activity in Croatia. Table 3 shows that the human capital structure is clearly the most desirable in NWC, contributing to a more favourable innovation eco-environment. Moreover, in 2008-10 NWC leads in the share of population with highest level education (20.9\%) and in Masters and Specialist degrees $(5.0 \%)$ and Doctors of Science in the Students graduated population (5.5\%). On the other hand, the dynamics of AC tertiary education indicators is indicating the process of catching up with NWC. The share of population with higher level education, students enrolled and students graduated as shares in the population of 20-24 years of age are the highest in AC.

NWC benefits from a concentration of scientific institutions. Academic staff per institution is similar in NWC and $\mathrm{AC}$, while CEC's scientific institutions on average have smaller academic capacities. Discrepancies between CEC and the leading region are most visible in the shares of population with highest level education and students enrolled (11 and 12 percentage points lower than in NWC in 2008-10 period). However, visible progress has been achieved in the students graduated share with a 4-percentage-points rise between periods.

Scientific output dynamics across three regions are a clear point of strong regional differentiation. Compared to the 20062008 period, a surge in the number of scientific papers was most notable in AC and NWC (by 12 and 9 papers per institution, respectively) and least expansive in CEC (by only 2 papers).

\section{Firm innovation activity}

The evidence of innovation activity comes from Croatian CIS data (CBS-CIS) from two consecutive two-year periods. In the period 2006-08, the sample consisted of 3,404 firms (48\% from 
DRUŠ. ISTRAŽ. ZAGREB GOD. 25 (2016), BR. 2 STR. $157-178$

BAČIĆ, K., ARALICA, Z. INNOVATION SYSTEMS...
NWC, 24\% from CEC and 28\% from AC), while in the period 2008-10, the sample consisted of 3,390 firms (49\% from NWC, $22.5 \%$ from CEC and $28.5 \%$ from AC). The data show that innovative firms are larger (Table 4): in 2008-10 roughly 148 employees per firm in NWC, 93 in CEC and 97 in AC. This is consistent with CBS's findings (2008k) for the period 2004-06 for the national level: innovative firms were mostly larger firms (55.6\%), and less medium (39.3\%) and small (23.0\%) firms.

Innovative firms located in NWC are larger than in the other two regions and their share of employees with University degree is highest, between 5-9\%, while in AC and CEC this share is between $1-4 \%$. The industrial structure determined from the CIS sample is technologically the most complex in NWC in both observed periods, as is the share of innovative firms, in line with Arbussa and Coenders's finding (2007) that technologically advanced subsectors usually report the highest rates of innovation. NWC firms' share in 2008-10 is the highest in the high technology-intensive industry with $2 \%$ (compared to $0.9 \%$ and $0.6 \%$ in CEC and AC), in the medium-high technology-intensive industry it is 7\% (5\% and $4.1 \%$ in CEC and AC) and it is unrivalled in the knowledge-intensive service industry with a $19.2 \%$ share $(7.3 \%$ and $11.5 \%$ in CEC and AC). A distinct feature of CEC is the dominance of low technology-intensive industry with a $27.1 \%$ share, and in $\mathrm{AC}$ it is the dominance of low-knowledge intensive-service industry with a $29.4 \%$ share, with the dominance of tourism as an economic activity.

The share of innovative firms in the sample in NWC is $50.2 \%$, and in CEC and AC $-40.4 \%$ and $40.2 \%$, respectively. Similar shares of innovative firms in AC and CEC contrast with CEC's less favourable indicators across a number of RIS sub-dimensions. When the more favourable innovation ecoenvironment is taken into consideration in $\mathrm{AC}$, it can be argued that firms in $\mathrm{AC}$ are under-performing in innovation activity. Thus, within-firm strengths and/or inter-firm cooperation at the regional level are likely to be the avenues of differentiation of innovative activities among these two regions. Data on innovation input in the two periods support this view, particularly in the case of CEC. In 2006-08, CEC's firm spending on acquisition of machinery, equipment and software is second to NWC's, while in the following period CEC has invested most. Acquisition of external knowledge such as licences, patents and know-how does not appear a determinant of innovation output for firms in CEC as they have spent the least in this category in both periods. Innovation input in all three regions has plummeted between the two periods as a result of the recession in 2008 . 
DRUŠ. ISTRAŽ. ZAGREB GOD. 25 (2016), BR. 2, STR. $157-178$

BAČIĆ, K., ARALICA, Z.: INNOVATION SYSTEMS..
Data on innovation output across both periods are surprising - although NWC has the highest share of innovative firms, their performance measured in turnover from significantly improved products introduced new to market/new to firm is consistently below the other two regions throughout both periods. In the $2008-10$ period this share was at $31.8 \%$ and $33.4 \%$ in CEC and AC and $28.8 \%$ in NWC. One of the explanations for this may be that firms in NWC are facing tougher competition and/or revenues from already established products are more important in their turnover.

\section{System's performance}

A set of indicators composing the final systemic dimension is used with the purpose to check whether RISs in Croatia are functional with respect to the Triple Helix context. It can be argued that a competitive and strong industrial sector is the foundation of a national and (regional) system of innovation. Given the fact that the process of deindustrialisation has reduced the industrial base across regions, this foundation in Croatia can be considered weak. Gross value added (GVA) per employee in industry, used as an indicator of technological complexity in production, is the highest in NWC (at 227.300 kuna in 2008-10). NWC is also leading in the number of employed in SME per capita (16.8), further pointing to comparatively stronger economic dynamics.

GVA per employee in industry in 2008-10 in AC is second to NWC, at 195.200 kuna. AC is leading in SME investment into new long-term assets as a share in total revenues $(8.2 \%)$ in $2008-10$ (NWC is at $5.3 \%$ ). CEC is the least competitive region according to a number of relevant social and economic indicators in 2007 and in 2010 (NCC and UNDPPC, 2011). GVA per employee in industry and SME indicators are least favourable for CEC. Slow progress in industry revival and in entrepreneurial activity has resulted in a pro-active public approach to developing entrepreneurial infrastructure, mostly visible in the rising surface per capita of business zones, in 2006-08 levelling out across the three regions.

The percentage of firms that report receiving financing from national authorities is the highest in CEC in both consecutive periods $(29.6 \%$ and $30.4 \%$, respectively), followed by NWC $(22.2 \%$ and $24.6 \%)$ and AC $(21.2 \%$ and $17.6 \%)$. The highest share of local \& regional financing of innovative firms is also reported in CEC in 2006-08 (8.1\%), while in 2008-10, this share is the same in NWC and CEC (5.4\%) and lower in AC $(4.2 \%)$. CEC's better access to public financing could be the determining factor of its level of diffusion of innovation being comparable to AC's in 2008-10. EC (2014) reports that regions with high shares of innovative companies that addi- 
DRUŠ. ISTRAŽ. ZAGREB GOD. 25 (2016), BR. 2 STR. $157-178$

BAČIĆ, K., ARALICA, Z. INNOVATION SYSTEMS... tionally have a developed system of public financing are more innovative.

The percentage of firms perceiving internal, market and institutional sources of information about innovation importance is the highest in NWC. The perception of importance of these sources falls in all three regions between the two periods, most likely as a result of the narrowing of innovation perspectives during recession. Market sources are the most important in all three regions (34.5\% NWC, $26.9 \%$ in CEC and $25.2 \%$ in AC in 2008-10), followed by internal sources. Some regional differences can be noted: the difference in the share of firms that found market sources more important than internal sources is more pronounced in AC (5.5 percentage points) than in NWC and CEC (3.4 and 3.3 percentage points).

The potential of industry-science-government cooperation in Croatian regions can be observed through the shares of firms perceiving institutional information sources as important. They prove to be the least important. Moreover, these shares have dropped in all three regions between the two periods, and in CEC and AC they were halved. Firms-science cooperation's perception has thus proven most sensitive to the changes in economic outlook. In 2008-10 the share of firms that found institutional sources such as universities and research institutes important was 7.8\% in NWC, 5.2\% in CEC and $4.2 \%$ in AC. These values support Radas's findings (2005) that Croatian firms face the inability to commercialise the results of the cooperation with science based on a research of 190 enterprises registered in activities demanding $R \& D$ investment and in high-technology activities in 2002.

Weak perception of the importance of institutional sources is reflecting an early stage transformation to modern innovation policy and associated commercialisation of scientific output. Regional innovation infrastructure that supports activities related to knowledge transfer has largely relied on national innovation policy and its constituent programs in its development, most notably the Program for the Technological Development of Croatia - TEHCRO. Support also came from county and/or local institutions that saw their interest in tackling entrepreneurial activity. Apart from business zones, this is best reflected in the fast rising number of business incubators (BIs) as hubs of innovative start-ups in post-2000, mostly integral to wider infrastructural concepts such as business zones, technological parks (TPs) and innovation centres. The negative aspect of regional BIs' development is that it has been unsystematic, with lacking analysis of actual business needs (Bošnjak, 2011, pp. 51).

TPs and technology development centres (TDCs) as the most-complex and highly-potent part of technological infra- 
DRUŠ. ISTRAŽ. ZAGREB GOD. 25 (2016), BR. 2, STR. $157-178$

BAČIĆ, K., ARALICA, Z.: INNOVATION SYSTEMS..

(1) TABLE 4

Dynamics of establishing selected innovation infrastructure in Croatian regions up to 2010 structure tied to Universities, established by several interested "regional" parties - cities, private firms and counties, and, in some cases, central government bodies ensure more potent innovation activity support through various services (Table 4). The post-2000 period is the early phase of regional technological infrastructure operations. TPs and TDCs mostly provide office space for start-ups and incubating services, proof-of-concept, business model development and assist in finding finances. A common factor is the focus to attracting tenants from innovative business activities, mostly in ICT. The main focus of these institutions in the observed period is mostly in supporting potentially innovative entrepreneurship. For example, in Technology Park Varaždin, the number of tenants' employees has in the 2007-09 period grown from 40 to 157 with one prototype developed, two new products/services developed and two patents (Mateša, Žorž, Osredečki, \& Nagy, 2010).

\begin{tabular}{|c|c|c|}
\hline North-West Croatia & Central and East Croatia & Adriatic Croatia \\
\hline \multicolumn{3}{|c|}{ Technology parks (TP) } \\
\hline Zagreb TP (1993), RAZA since 2007 & & $\begin{array}{l}\text { The Science and TP of the } \\
\text { University of Rijeka - Step Ri (2008) }\end{array}$ \\
\hline
\end{tabular}

Technology development \& transfer centres and related institutions

Technology Transfer Centre at Faculty of Mechanical Engineering and Naval Architecture, University of Zagreb (1996)

Ruđer Innovation (2007)

\author{
Technology Development Centre \\ in Osijek \\ TeraTehnopolis (2002) \\ Technology Innovation Centre \\ Međimurje (2010), Regional \\ Development Agency Međimurje
}

\author{
Technology Centre Split (1997) \\ Technology-Innovation Centre \\ of Rijeka (1997)
}

Mariculture Business Innovation Centre of the University of Dubrovnik - MARIBIC (2008)

The Research Centre for Material in the Region of Istria - METRIS,

Istrian Development Agency (2009)

Technology transfer offices at Universities

Centre for Research, Development and Technology Transfer at University of Zagreb (2010)

\author{
Technology Transfer Office - \\ University of Split (2007) \\ Technology Transfer Office - \\ University of Rijeka (2009)
}

Business incubators providing technology and know-how transfer services

Business incubator BIOS, Osijek (1996)

Business-technology incubator (2006),

Industrial park Nova Gradiška

Source: Authors using Business Croatia and institutional web-sites. 
DRUŠ. ISTRAŽ. ZAGREB GOD. 25 (2016), BR. 2 STR. $157-178$

BAČIĆ, K., ARALICA, Z. INNOVATION SYSTEMS...

\section{CONCLUSION}

Research institutes are potentially important contributors to innovation activity through technology transfer. Ruđer Innovation situated in NWC, as a daughter-firm of Ruđer Bošković Institute, is the first example of an operative technology transfer hub with four spin-offs (RBI, 2014). The focus on technology transfer at public universities is seen in the late 1990s through establishing Technology Transfer Offices (TTOs). However, TTOs have in their activity remained at the periphery of University activities with scarce resources (Švarc, 2009) and a true promotion of commercialisation of scientific research was seen throughout the process of drafting the Smart Specialisation Strategy for Croatia.

Analysis has revealed a heterogeneity of innovation capacities and regional strengths in three Croatian regions at NUTS II level in 2006-10. Drawing on these findings, it is possible to discern the existence of several RIS as socio-institutional systems in space that have developed along with the dynamics of technological infrastructure development and are unconstrained by NUTS II level. The most potent innovative capacities in Croatia are concentrated in four urban centres Zagreb, Split, Rijeka and Osijek. These cities can play a major role in the development of RIS in Croatia, as technological infrastructure is most developed in these cities that are also major economic and university centres. Furthermore, the applied analytical framework has been useful for recognising that there are actual policy needs in this area. In the light of this, some policy recommendations are offered.

Research has shown that the region with the highest share of firms with diffusion of innovation (roughly $50.2 \%$ in 2008-10) is the most developed region - NWC (with GDP per capita at 12.278 EUR in 2010). Research shows that in the observed period all three regions were in the early phase of business-science-government cooperation. However, NWC has the highest potential to capitalise on these interactions due to the concentration of leading scientific institutions, presence of well-established firms and a strong pool of highly qualified labour force. These factors are NWC's main regional strengths, supportive of innovative activity as a source of regional competitiveness. Firms as main agents in the innovation activity are on average larger, with both in-house and external R\&D several times larger in NWC compared to the other two regions. NWC's more diversified economic structure has larger shares of high-value added activities that are more orientated towards innovation activity, such as knowledge-intensive services, medium-high technology intensive industry and high technology industry. 
DRUŠ. ISTRAŽ. ZAGREB GOD. 25 (2016), BR. 2, STR. $157-178$

BAČIĆ, K., ARALICA, Z.: INNOVATION SYSTEMS...
Within NWC, two RISs with well-developed technological infrastructure and a true potential to become "multidimensional" can be recognised - one is formed around the capital city Zagreb and the other around the city of Varaždin. Zagreb-based RIS is clearly benefitting from Zagreb's agglomeration economies, strong international trade and capital flows with potential for knowledge spillovers, while Varaždin-based RIS benefits from an established technological park and two influential local innovation systems of several northern counties - County of Međimurje and County of Koprivnica-Križevci, as well as from a dynamic regional economy. Regional goals for the NWC area should be better positioning of regional industries in the global knowledge economy, via encouraging development of relevant and internationally visible products. Thanks to NWC's international profile, this can partially be addressed through innovation collaboration with firms in other European counties, as deemed in the case of smaller European countries (Knell, 2011). The first successful cases of science-industry cooperation can be used to further promote this type of cooperation and contribute to increasing science-based production in NWC. Regional strengths identified within RIS can further be supported via tailor-made local policies. The regional science sector should make progress in communicating its research findings more articulately and pro-actively to the business sector, thus building interactions and creating more opportunities for the commercialisation of research output.

AC has a number of regional advantages over CEC, yet the share of innovative firms in $\mathrm{CEC}$ and $\mathrm{AC}$ is at roughly the same level (40.4\% and $40.2 \%$, respectively in $2008-10)$, suggesting that $\mathrm{AC}$ is underperforming in its regional innovation activity. AC's GVA per employee in industry is $38 \%$ higher than in CEC in 2008-10. Furthermore, AC is better integrated in international trade and capital flows than CEC. The dynamics of AC in tertiary education and scientific output are indicating a faster catching up to NWC. Rijeka-centred RIS can be recognised in AC, with the city of Rijeka traditionally being a strong industry centre that has a well-performing science \& technology park. Another RIS can be mapped as Split-centred, with the city of Zadar emerging as a possible strong local innovation system due to noted local policy success in supporting specialisation in the film industry (INOVAcija, 2016). For the AC region, with strong specialisation in low-knowledge intensive services, knowledge and skills match is a priority. Local policies should advocate regular screening of sectoral needs for skills and adapt education strategies accordingly. New economic activities should be encouraged to allow for more diversification of the regional economy and 
DRUŠ. ISTRAŽ. ZAGREB GOD. 25 (2016), BR. 2 STR. $157-178$

BAČIĆ, K., ARALICA, Z.: INNOVATION SYSTEMS... relieve reliance on tourism. Policies that should allow and encourage research institutions and technological infrastructure to be more open and responsive to the R\&D issues faced by firms in this region, should be developed.

CEC's obvious advantage appears to be its firms' good access to public financing, evident in the share of firms (30.4\%) receiving financial support from national authorities in 2008-10, compared to AC (17.6\%). CEC has a strong regional value chain that includes agriculture and traditional low-technology industries, and the need of firms in CEC for technological upgrading is achieved mainly through external $R \& D$ acquisition. An expansion in knowledge-intensive services is most likely a response to those needs. Osijek-centred RIS is discernible in this region, and an advanced local innovation system in Nova Gradiška. With SMEs being the dominant type of business entities, CEC should tailor policies supportive of SMEs' innovation activity. Regional governance should also be supportive of strengthening the international cooperation of firms. With regard to sectoral structure, the preferred policy emphasis should be on medium-level skills development. Technical and engineering schools are crucial to this region.

\section{NOTES}

${ }^{1}$ Enablers consist of Human resources-, Finance and support indicators. Firm activities consist of Firm investments-, Linkage \& entrepreneurship-, Intellectual assets indicators. Outputs consist of Innovators- and Economic effects' indicators.

2 FINA gospodarske vijesti (2009). Available at http://www.fina.hr/Default. aspx?art $=11013 \&$ sec $=1722$.

\section{REFERENCES}

Arbussa, A., \& Coenders, G. (2007). Innovation activities, use of appropriation instruments and absorptive capacity: Evidence from Spanish firms. Research Policy, 36(10), 1545-1558.

Bošnjak, S. (2011). Poslovni inkubatori kao generator razvoja poduzetništva (Business incubators as a generator of the development of entrepreneurship). Praktični menadžment, II(2), 51-56.

Božić, L., \& Botrić, V. (2014). Inovativnost i struktura radne snage u Hrvatskoj - sektorski pristup (Innovativeness and workforce structure in Croatia - sector approach). In V. Cini, Đ. Borozan, \& I. Ferenčak (Eds.), Konkurentnost, ekonomski rast i blagostanje (Competitiveness, economic growth and prosperity) (pp. 146-162). Osijek: J. J. Strossmayer University in Osijek, The Faculty of Economics.

Cooke, P., \& Memedovic, O. (2003). Strategies for regional innovation systems: Learning transfer and applications, UNIDO, Vienna. Available at http://www.unido.org/fileadmin/user_media/Publications/Pub_ free/Strategies_for_regional_innovation_systems.pdf 
DRUŠ. ISTRAŽ. ZAGREB GOD. 25 (2016), BR. 2, STR. $157-178$

BAČIĆ, K., ARALICA, Z.: INNOVATION SYSTEMS...
Dabić, M., \& Švarc, J. (2012). O konceptu poduzetničkoga sveučilišta: Ima li alternative? (About the concept of entrepreneurial university: Is there an alternative?). Društvena istraživanja, 20(4), 991-1013. doi:10. 5559/di.20.4.04

Doloreux, D., \& Parto, S. (2005). Regional innovation systems: Current discourse and unresolved issues. Technology in Society, 27(2), 133-154. doi:10.1016/j.techsoc.2005.01.002

Đokić, I., Fröchlich, Z., \& Rašić-Bakarić, I. (2016). The impact of the economic crisis on regional disparities in Croatia. Cambridge Journal of Regions, Economy and Society, 9(1), 179-195. doi:10.1093/cjres/rsv030. EC - European Commission (2014). Regional Innovation Scoreboard 2014. Available at http://ec.europa.eu/enterprise/policies/innovation/ files/ris/ris-2014_en.pdf

EC - European Commission (2015). Innovation Union Scoreboard. Available at http://ec.europa.eu/growth/industry/innovation/factsfigures/scoreboards/files/ius-2015_en.pdf

Edquist, C. (2004). Systems of innovation - a critical review of the state of the art. In J. Fagerberg, D. Mowery, \& R. Nelson, Oxford Handbook of Innovation (pp. 181-208). Oxford: Oxford University Press.

EIZ - The Institute of Economics (2016). Projections of the future needs of the labour market PROLAB (project study). Available at http://www. eizg.hr/en-US/Projections-of-the-futureneeds-of-the-labour-market(PROLAB)-1560.aspx

Etzkowitz, H., \& Leydesdorff, L. (1995). The triple helix - university-industry-government relations: A laboratory for knowledge based economic development. EASST Review, 14(1), 14-19. Available at http://papers.ssrn.com/sol3/papers.cfm?abstract id $=2480085$

Eurostat (2015). NUTS - Nomenclature of territorial units for statistics-Overview. Available at http://ec.europa.eu/eurostat/web/nuts/ overview

Evangelista, R., Iammarino, S., Mastrostefano, V., \& Silvani, A. (2001). Measuring the regional dimension of innovation. Lessons from the Italian Innovation Survey. Technovation, 21, 733-745.

Hansen, T., \& Winther, L. (2011). Innovation, regional development and relations between high- and low-tech industries. European Urban and Regional Studies, 18, 321-339.

Hashi, I., \& Stojčić, N. (2013). The impact of innovation activities on firm performance using a multi-stage model: Evidence from the Community Innovation Survey 4. Research Policy, 42(2), 353-366.

INOVAcija - Ustanova za razvoj kompetencija, inovacija i specijalizacije Zadarske županije (INOVAcija - The institution for development of competence, innovation and specialisation of Zadar County). Available at http://www.inovacija-zadar.hr/o-nama/

JRC-Joint Research Center of the European Commission (2013). EU Regional Competitiveness Index 2013, Available at http://ec.europa. eu/regional_policy/sources/docgener/studies/pdf/6th_report/rci_201 3_report_final.pdf

Knell, M. (2011). Global Networks of innovators: A synthesis of research issues. Paper presented at the DIME Final Conference, 6-8 April 2011, Maastricht. 
DRUŠ. ISTRAŽ. ZAGREB GOD. 25 (2016), BR. 2 STR. 157-178

BAČIĆ, K., ARALICA, Z.: INNOVATION SYSTEMS...
Mateša, Z., Žorž, I., Osredečki, G., \& Nagy, I. (2010). Best practice analysis of innovative business incubators in Croatia, Case study of the Technology Park Varaždin. FIDIBE. Available at http://www.southeasteurope.net/document.cmt?id=116

McCann, P., \& Ortega-Argilés, R. (2013). Modern regional innovation policy. Cambridge Journal of Regions, Economy and Society, 6, 187-216. doi:10.1093/cjres/rst007

NCC and UNDPPC (2011). National Competitiveness Council and UNDP Programme Croatia, Regionalni indeks konkurentnosti Hrvatske 2010, Zagreb. Available at http://www.konkurentnost.hr/ lgs.axd? $\mathrm{t}=16 \& \mathrm{id}=331$

OECD (2011). Regions and Innovation policy, OECD reviews of Regional Innovation, OECD Publishing. doi:10.1787/9789264097803-en

Radas, S. (2005). Motivacijski faktori, intenzitet i rezultati suradnje gospodarstva i znanosti (Relationship between enterprises and scientists: Motivation factors, collaboration intensity and collaboration outcome). Privredna kretanja i ekonomska politika, 102, 61-80.

RBI - Ruđer Bošković Institute web-site: Industry - Rudjer Innovations Ltd. Available at https://www.irb.hr/eng/Industry/RudjerInnovations-Ltd

Švarc, J. (2006). Socio-political factors and the failure of innovation policy in Croatia as a country in transition. Research Policy, 35, 144-159.

Švarc, J. (2009). Hrvatska u društvu znanja: prijepori i perspektive inovacijske politike (Croatia in the knowledge society: Perspectives and dilemmas of innovation policy). Zagreb: Školska knjiga.

Zabala-Iturriagagoitia, J. M., Jiménez-Sáez, F., Castro-Martinez, E., \& Gutiérrez-Gracia, A. (2007). What indicators do (or do not) tell us about Regional Innovation Systems. Scientometrics, 70(1), 85-106.

\section{SOURCES OF DATA}

BC - Business Croatia at http://www.poslovna.hr/

CBS - CIS: The Croatian Bureau of Statistics - Community Innovation Survey Dataset 2006-2008; 2008-2010

CBS (a) - Census 2001

CBS (b) - Census 2011

CBS (c) - Statistical Yearbook 2011

CBS (d) - Statistical Yearbook 2008

CBS (e) - Statistical report 1444.

CBS (f) - Statistical report 1387. (2010)

CBS (g) - First release 12.1.5.; 12.1.2.

CBS (h) - First release 4.2.2.

CBS (i) - Statistical report, 1307, 1364, 1476, 1419

CBS (j) - First release 8.2.2.

CROSBI - Croatian Scientific Bibliography at https://bib.irb.hr

MSES - Ministry of Science, Education and Sports. Available at http://pregledi.mzos.hr/Ustanove_Z.aspx 
DRUŠ. ISTRAŽ. ZAGREB GOD. 25 (2016), BR. 2, STR. $157-178$

BAČIĆ, K., ARALICA, Z.: INNOVATION SYSTEMS...

\section{Inovacijski sustavi u hrvatskim regijama}

Katarina BAČIĆ, Zoran ARALICA

Ekonomski institut, Zagreb

Cili je ovoga rada istražiti koncepciju regionalnih inovacijskih sustava (RIS) i primijeniti je na hrvatske regije, pa potom prepoznati regionalne prednosti koje podržavaju difuziju inovacija kao izvor regionalne konkurentnosti. S tom svrhom osmišljen je sustar pokazatelja, s time da se u izboru dimenzija i pokazatelia toga sustava uvelike slijedio rad autora Evangelista, lammarino, Mastrostefano i Silvani (2001). Ukupno 32 regionalna indikatora svrstana su u tri dimenzije RIS-a, a to su: stvaranje i diseminacija znanja; inovaciiska aktivnost poduzeća i učinkovitost sustava. Među regijama je zamijećena heterogenost u pogledu inovacijskih kapaciteta između 2006. i 2010. godine. Sjeverozapadna Hrvatska vodeća je u difuziiji inovacija s RIS-om koji ima najbolje preduvjete za razvoj inovaciiskih aktivnosti. Središnja $i$ istočna Hrvatska $(\mathrm{SIH})$ ima specifičan lanac vrijednosti u poljoprivredi i niskotehnološkim industrijama te industrije u ovoj regiii svoje potrebe za tehnološkim unapređenjem rješavaju ulaganjem u I\&R izvan poduzeća (stjecanjem licencija, patenata i know-howa), uz snažnu podršku javnih izvora financiranja. Jadranska Hrvatska ostvaruje slabije rezultate $u$ inovacijskim aktivnostima kada se razmotre prednosti koje ova regija ima u usporedbi sa SIH u važnim elementima sistemskih dimenzija kao što su poduzetnička i tehnološka infrastruktura te znanstveni kapaciteti. Na osnovi opaženih regionalnih razlika $u$ inovaciiskim kapacitetima dane su preporuke za relevantne politike, poštujući pritom i sektorske razlike među regijama.

Ključne riječi: regionalni inovacijski sustavi (RIS), hrvatske regije, inovacijske aktivnosti, difuzija inovacija 